\title{
Inhibition of cellular autophagy in proximal tubular cells of the kidney in streptozotocin-diabetic and uninephrectomized rats
}

\author{
Aryon de Almeida Barbosa $\mathrm{Jr}^{1}$, Hui Zhou ${ }^{2}$, Dieter Hültenschmidt ${ }^{2}$, Vladimir Totovic ${ }^{2}$, Nenad Jurilj ${ }^{3}$, \\ and Ulrich Pfeifer ${ }^{2}$ \\ ${ }^{1}$ Centro de Pesquisas Conçalo Moniz (FIOCRUZ), R. Valdemar Falcao, 121-Brotas, 40.000-Salvador, Bahia, Brazil \\ ${ }^{2}$ Department of Pathology, University of Bonn, Postfach 2121, W-5300 Bonn, Federal Republic of Germany \\ ${ }^{3}$ Department of Biology, Stomatological Faculty, University of Zagreb, Yugoslavia
}

Received September 26 / Accepted December 11, 1991

Summary. To examine the significance of anti-catabolism in renal hypertrophy, cellular autophagy was investigated by electron microscopic morphometry in proximal tubular cells (PTCs) of the outer cortex of the rat kidney after the induction of diabetes mellitus by streptozotocin (STZ) and after unilateral nephrectomy. Adult male Sprague-Dawley rats were divided into three groups and killed by retrograde perfusion fixation, 1,2 and 3 days after the induction of diabetes (group D; $n=24$ ), after unilateral nephrectomy (group $N ; n=24$ ) and after combined treatment (group DN; $n=24$ ). Untreated, agematched litter mates served as controls (group $C ; n=$ 24). By comparison with these controls, the left kidney to initial body weight ratio was increased by 8,23 , and $15 \%$ in group D animals, by 8,23 , and $24 \%$ in group $\mathrm{N}$ animals, and by 10,21 , and $25 \%$ in group $\mathrm{DN}$ animals at the first, second and third day, respectively. Quantitative evaluation of large test areas showed that the volume and numerical densities of autophagic vacuoles (AVs) in PTCs were significantly lower in these hypertrophed kidneys than in the controls. The average reduction in AV volume density was about $65 \%$ in group $\mathrm{D}$ animals, about $50 \%$ in group $\mathrm{N}$ animals and about $75 \%$ in group DN animals. These data show that autophagic degradation of cytoplasmic components in PTCs is inhibited in renal hypertrophy independently of the growth stimulus, i.e. uninephrectomy or diabetes. Since insulin per se inhibits cellular autophagy in PTCs, the expected effect of insulin dificiency seems to be counteracted by as yet undefined stimuli that may be related to metabolic work load.

Key words: Cellular autophagy - Ultrastructural morphometry-Proximal tubules - Adaptative hypertrophy - Uninephrectomy-Experimental diabetes

\section{Introduction}

Cellular autophagy is a well known process whereby cytoplasmatic constituents are enclosed by membranes and sequestered into the lysosomal compartment for eventual digestion (Pfeifer 1976; Marzella and Glaumann 1980; Glaumann et al. 1981; Glaumann and Ahlberg 1987). Autophagic vacuoles (AVs) are formed under physiological conditions in PTCs of the kidney and in liver cells (Pfeifer and Warmuth-Metz 1983). The importance of AVs for intracellular protein degradation has been convincingly shown in numerous experiments (Seglen et al. 1979; Furano et al. 1982; Henell and Glaumann 1984; Henell et al. 1987). In addition, quantitative electron microscopic studies (Pfeifer and Bertling 1977; Pfeifer and Jurilj 1979; Dämmrich and Pfeifer 1983; Jurilj and Pfeifer 1985, 1990; Müller et al. 1987) have demonstrated that inhibition of the autophagic process, expressed morphologically by a reduction in the volume and numerical densities of AVs, plays a prominent role in induced growth processes (for review, see Pfeifer 1982).

Renal enlargement, a model of localized tissue growth, has been interpreted as a response by the kidney to an increased work load after uninephrectomy (Hayslett 1979; Hostetter et al. 1981; Chevalier 1982; Finn 1982; Fleck and Bräunlich 1984; Fine 1986), and similar considerations evolved from the observations of kidney growth in early experimental and human diabetes (Mogensen et al. 1979, 1981; Hirose et al. 1980; Jensen et al. 1981; Seyer-Hansen 1983; Osterby 1986; Viberti and Wiseman 1986; Bank et al. 1988; Flyvbjerg et al. 1988; Kleinman and Fine 1988; Kunjara et al. 1988). Additive effects on renal enlargement in rats have been found when experimental diabetes and uninephrectomy were combined (Ross and Goldman 1971; Seyer-Hansen 1978), but at present the mechanisms responsible for kidney growth in diabetic rats or compensatory growth after uninephrectomy are only partially understood (Rasch and Rytter-Nörgaard 1983). 
Since previous studies have shown that insulin inhibits the formation of AVs in renal PTCs (Pfeifer and Warmuth-Metz 1983) the question arises whether insulin deficiency in STZ diabetes leads to the expected enhancement of cellular autophagy in the kidney, or whether cellular autophagy is inhibited as in other experimental models of organ hypertrophy (Hill and Malamud 1974; Dämmrich and Pfeifer 1983; Müller et al. 1987; Jurilj and Pfeifer 1990).

\section{Materials and methods}

Animals. A total of 96 male Sprague-Dawley SPF rats (D. Wenzel, Detmold, FRG), weighing 200-250 g at the start of the experiment, were used. They were acclimatized for at least 7 days to the housing conditions with constant temperature $\left(22^{\circ} \mathrm{C}\right)$ and automatic light control (dark between 7:00 p.m. and 7:00 a.m.). The rats were housed two in each cage and were fed standard commercial rat pellets (ALTROMIN 1324, Altromin GmbH, Lage, FRG). Food and water were given ad libitum

Experimental conditions. Because of the well-known circadian variations in cellular autophagy (Pfeifer and Scheller 1975), the experiments were restricted to intervals between 10:00 a.m. and 12 noon, requiring repeated investigation each involving a limited number of animals. In these single experiments at least one animal was included from each group, i.e. diabetic (D), unilateral nephrectomised $(\mathrm{N})$, combined diabetic and unilateral nephrectomised (DN), and untreated age-matched controls $(\mathrm{C})$. The final number of animals was 24 in each group.

Diabetes was induced by a single intravenous injection of STZ (Serva, Heidelberg, FRG), $65 \mathrm{mg} / \mathrm{kg}$ body weight, into the tail vein. Rats with blood glucose, levels above $400 \mathrm{mg} / \mathrm{dl}$ were considered diabetic. Rats that failed to show an elevated blood glucose level were excluded from the study.

Right-sided nephrectomy, leaving the adrenal gland undamaged, was performed through a flank incision under sodium pentobarbital anesthesia (Nembutal, Ceva, Bad Segeberg, FRG), $40 \mathrm{mg} /$ $\mathrm{kg}$ body weight given intraperitonially. In the DN group, nephrectomy was performed immediately after the STZ injection.

Vascular perfusion fixation method. The animals were anesthethized with intraperitoneal injection of sodium pentobarbital $(50 \mathrm{mg} / \mathrm{kg}$ body weight). The abdominal cavity was opened by a midline incision with lateral extensions. The aorta just below the celiac artery was carefully exposed and a loose ligature placed around it. The superior mesenteric artery was clamped and the aorta below the origin of the renal arteries was exposed and freed from adipose tissue. An injection valve three-way stopcock (Mecath Inc, 17G/ $1.4 \mathrm{~mm}$ O.D. $\times 40 \mathrm{~mm}$, Codan Steritex Aps, Hojvangen, Espergaerde, Denmark) was inserted towards the heart into the lumen of the aorta about $1 \mathrm{~cm}$ from its bifurcation. Blood samples were taken and collected in Monovelle KF tubes (Sarstedt, Mümbrecht, FRG) and stored at $4^{\circ} \mathrm{C}$ until analyzed (approximately $2 \mathrm{~h}$ later). The ligature around the aorta was then rapidly tightened and the inferior vena cava was cut. Immediately after the perfusion had started the aorta was clamped just above the celiac artery.

By use of the three-way stopcock the perfusion system permitted switching from the rinsing to the fixative solution without a fall in perfusion pressure, which was kept at $148 \mathrm{~cm} \mathrm{H}_{2} \mathrm{O}$ (about $40 \mathrm{mmHg}$ ). The kidneys that failed to blanch immediately after the start of the perfusion were discarded. Each animal was first perfused with about $60 \mathrm{ml}$ of the rinsing solution for $60 \mathrm{sec}$ and then with $15 \mathrm{ml}$ of the fixative for $3 \mathrm{~min}$. The rinsing solution consisted of $0.08 \mathrm{M}$ sodium cacodylate buffer containing $4 \%$ dextran 35 (Serva, Heidelberg, FRG) and 3.5\% procaine (Serva, Heidelberg, FRG), pH 7.3, 370 mOsm. The fixative consisted of $3 \%$ glutaraldehyde in an $0.08 \mathrm{M}$ sodium cacodylate buffer containing

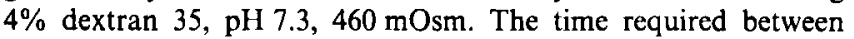
laparotomy and the start of perfusion was less than $4 \mathrm{~min}$.

Tissue preparation. After perfusion fixation the left kidney was excised and weighted. Cuboidal specimens (side length $1-1.5 \mathrm{~mm}$ ) were cut from the outer cortex. These specimens were immersed for $2.5 \mathrm{~h}$ in the same fixative used for perfusion, then rinsed in $0.08 \mathrm{M}$ sodium cacodylate buffer and postfixed in $2 \%$ osmium tetroxide in $0.14 \mathrm{M}$ phosphate buffer (Millonig 1962). They were then rinsed, dehydrated and embedded in Epon 812 (Luft 1961).

Sections were cut with a diamond knife on a LKB Ultratome UM3. Semithin sections were cut from three blocks at $1 \mu \mathrm{m}$ and stained with methylene blue-azur II (Richardson et al. 1960). One block from each animal was chosen and an area containing convoluted tubules was selected and trimmed for electron microscopy. Ultrathin sections $(50-70 \mathrm{~nm})$ were stained at room temperature with uranyl acetate and with a mixture of lead citrate, acetate and nitrate. The specimens were examined and photographed in a Siemens Elmiskop 101 electron microscope, operated at an acceleration voltage of $80 \mathrm{kV}$.

Morphometry. Autophagic vacuoles were identified according to the criteria of Pfeifer (1978) and counted directly on the EM screen. The square openings of the supporting copper grid (SCI G 200 HS cu $3.05 \mathrm{~mm}$, Science Services, Munich, FRG), which were completely covered by the section, were evaluated for AVs. Six fields per animal were viewed systematically for AVs after scanning at a primary magnification of $20,000 \times$.

By taking an electron micrograph at a primary magnification of $840 \mathrm{X}$, the total profile surface area of the proximal convoluted tubules in each square opening evaluated could be calculated. The fractional area covered by the PTCs was determined at a final magnification of $2100 \times$. An average profile surface area of PTCs per animal of $8700 \pm 1200 \mu \mathrm{m}^{2}$ of PTCs was evaluated. The total area of cytoplasm examined for AVs in this study was about $8.4 \times$ $10^{5} \mu \mathrm{m}^{2}$

Electron micrographs of all the AVs counted were taken at a primary magnification of $20,000 \times$ and were evaluated at a final magnification of $50,000 \times$.

The area of the sectioned proximal tubules and the area of the AV profiles photographed during the evaluation were measured by digitized morphometry using an IBM PC-AT computer and the Sigma-Scan Measurement System (Jandel Scientific, San Francisco, USA). The photomicrographs were placed on a digitizing opaque tablet and the structural contours traced with a cursor connected to the microprocessor to compute the respective areas in $\mu \mathrm{m}^{2}$. Latex particles of $1.05 \mu \mathrm{m}$ in diameter (Unisphere Latex, Serva, Heidelberg, FRG) and the bars of the copper grids supporting the specimens were used for the calibrations. The diameter of the bars from 15 randomly sampled grids were measured with an ocular micrometer by light microscopy. The mean thus obtained was $10.036( \pm 0.547) \mu \mathrm{m}$.

The AV volume density [Vv (AV/PTC)] was calculated as the quotient of the total AV profile area to the total area of the sectioned PTCs per animal. The number of AVs per unit volume of PTCs [Nv (AV/PTC)] was assessed by applying the formula of Weibel (1969). A spherical shape and a normal size distribution were assumed for this calculation.

Analytical procedure. Blood glucose was analyzed in the Institut für Klinische Biochemie, University of Bonn (Head: Prof. Dr. F. Bidlingmeier), by a hexokinase-glucose-6-phosphate dehydrogenase method (Merck System Glucose, Merck, Darmstadt, FRG) adapted for the EPOS Analyser 5060 (Eppendorf, Hamburg, FRG).

Statistical methods. An analysis of variance (ANOVA) and the U-test were performed with SAS software (SAS Institute, Heidelberg, FRG) and used to test the statistical significance. The limit of significance was set at $p<0.05$. 


\section{Results}

The results of the blood glucose analysis are plotted in Fig. 1. The blood glucose levels were significantly increased in the diabetic rats (groups $\mathrm{D}$ and $\mathrm{DN}$ ), the mean value being $466( \pm 47) \mathrm{mg} / \mathrm{dl}$, compared with the value found in the non-diabetic rats (groups $\mathrm{N}$ and $\mathrm{C}$ ) of $160( \pm 20) \mathrm{mg} / \mathrm{dl}(p<0.0001)$. Less than $5 \%$ of the animals that received STZ failed to show an elevated blood glucose level. The elevated glucose levels in the STZ-diabetic rats were fairly well maintained during the 3-day experimental period.

The average body weight did not change significantly within the first 3 days of the experiment. While a slight loss of body weight was noted in groups $\mathrm{D}$ and $\mathrm{DN}$, none could be detected in group $\mathrm{N}$.

The kidney weights determined after the fixation procedure were found to be increased in the $\mathrm{D}, \mathrm{N}$, and DN groups. When these changes were expressed as the ratio of the left kidney to the initial body weight, there was a substantial increase of $8 \%$ on the first, $23 \%$ on the second and $15 \%$ on the third day for group D animals, a gain of $8 \%, 23 \%$ and $24 \%$ for the group $\mathrm{N}$ animals, and an increase of $10 \%, 21 \%$ and $25 \%$ for the group DN animals, respectively, as compared with the corresponding controls. However, the ratios between kidney weight and body weight were not significantly different between the STZ-diabetic rats (groups D and $\mathrm{DN}$ ) and the nephrectomized rats (group N) during the entire experimental period (Fig. 2).

\section{Qualitative morphological findings}

A uniform and reproducible preservation of the proximal tubules with open lumina, evenly arranged brush border zones, and little or no apical swelling was obtained by the method applied. The occurrence of a brush border, of endocytic vesicles and vacuoles, of large lysosomal bodies, and of microbodies was taken to indicate a proximal tubular cell. No attempt was made to distinguish between the different segments of the proximal tubule.
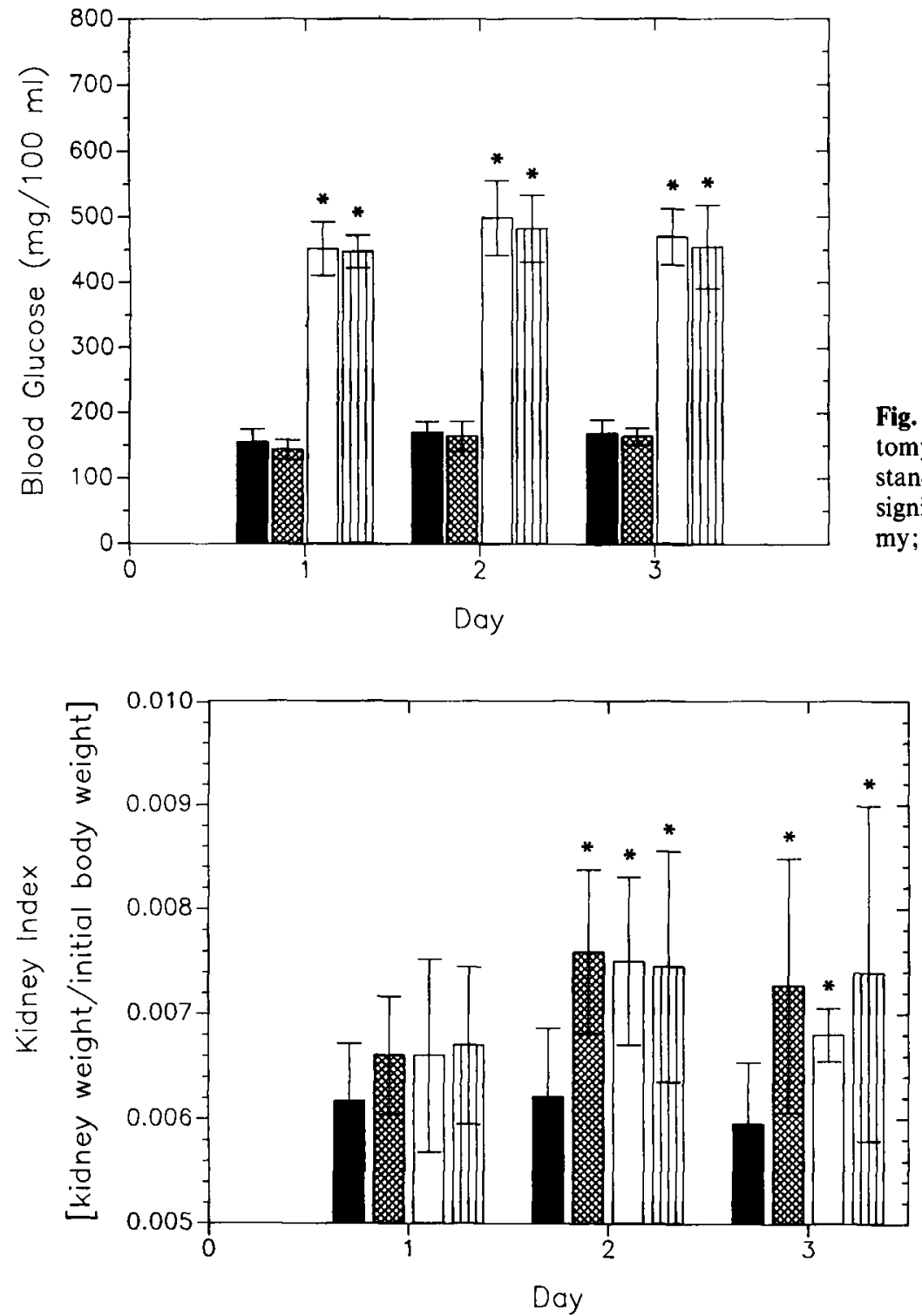

Fig. 1. Effects of STZ injection and/or unilateral nephrectomy on blood glucose levels $(\mathrm{mg} / \mathrm{dl})$. Values are means \pm standard deviation $(n=8)$. Asterisks denote statistically significant differences ( $U$-test) $\square$ Control; 2 nephrectomy; $\square$ diabetes; 四 diabetes and nephrectomy
Fig. 2. Effects of STZ-injection and/or nephrectomy on ratios of left kidney weight to initial body weight. Values are means \pm standard deviation $(n=$ 8). Asterisks denote statistically significant differences ( $U$-test) between the experimental groups and the corresponding control groups. For symbols see legend of Fig. 1 

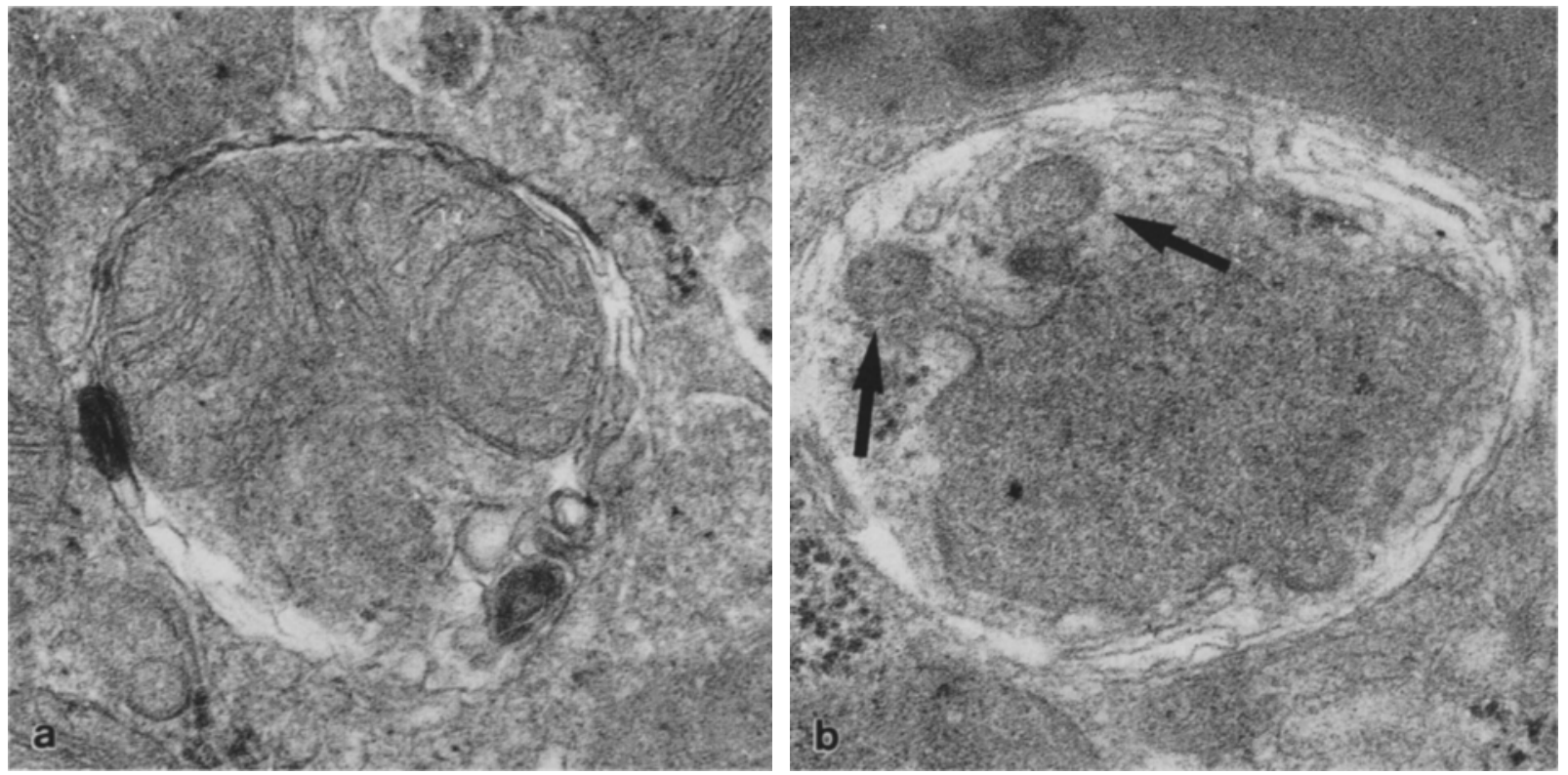

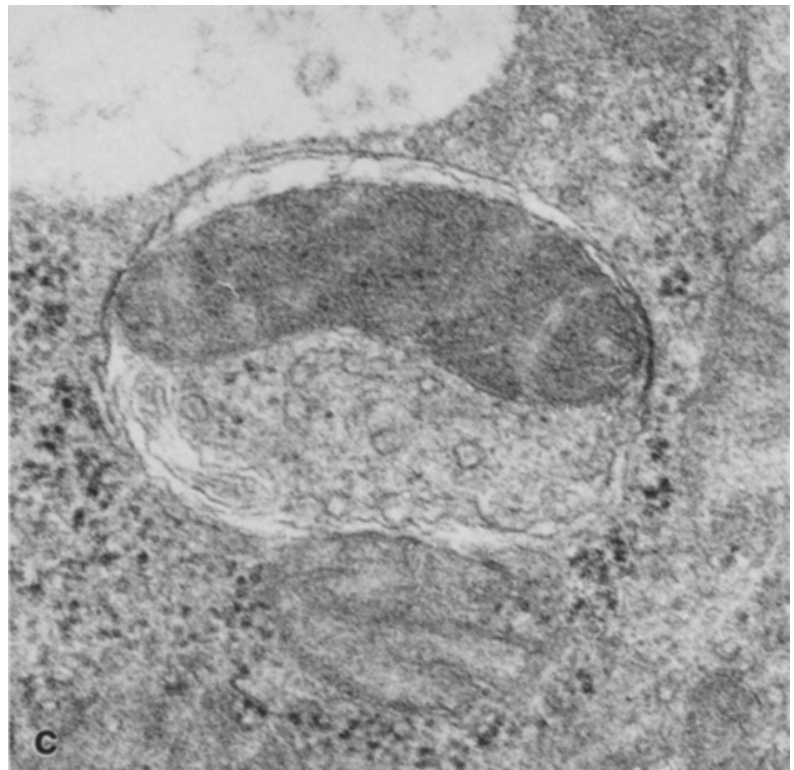

Fig. 3a-d. Different types of AVs in early stages. These are classified according to their contents: A mitochondria with well preserved cristae. Apparently the AV and two probable lysosomes are fusing. $b$ A portion of cyloplasmatic ground substance together with a peroxisome ( = microbody) identified by its single bordering membrane, its homogeneous matrix, as well as by cylindric struc-

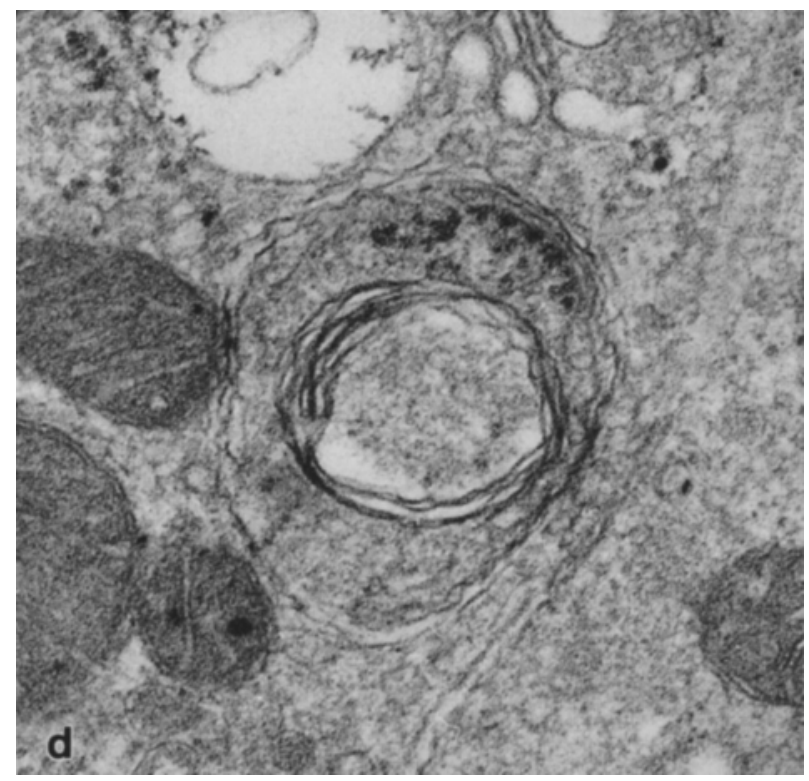

tures (arrows) which have been sectioned transversely. $\mathrm{c}$ A mitochondria and cytoplasmic ground substance together with small cisternae and vesicles. A AV containing a portion of cytoplasmic ground substance surrounded by the segregating structure which appears as a multiple membrane. $2-d \times 50,000$
The AVs were defined as areas of still recognizable cytoplasm, limited by a single or double membrane from the remaining cytoplasm, and were found in all regions of the tubular cells. When the segregated cytoplasm could no longer be clearly identified because of lytic changes, the profiles were excluded from the evaluation.

The AVs encountered during the systematic evaluation did not show qualitative morphological changes related to either the experimental condition or the time interval. The segregated cytoplasmic components in the proximal tubular cells of the rat kidney consist of mitochondria $(A V m)$, peroxisomes $(A V p)$, and, taken as one type, of ground substance, glycogen particles, profiles of endoplasmatic reticulum and of the Golgi-apparatus (A Vergs). Some AVs with "mixed" contents, or surrounded by multiple limiting membranes, were also noted (Fig. 3a-d).

Quantitative results. The volume density in the proximal tubular ccll cytoplasm of all the types of AVs is shown in Fig. 4 and in Table 1. When compared with controls, the volume density was found to be significantly decreased after STZ-injection (groups D and DN) and after nephrectomy (group $N$ ). The volume density of the AVs was lower in the animals after STZ-injection (group D) than after nephrectomy (group N), but this 

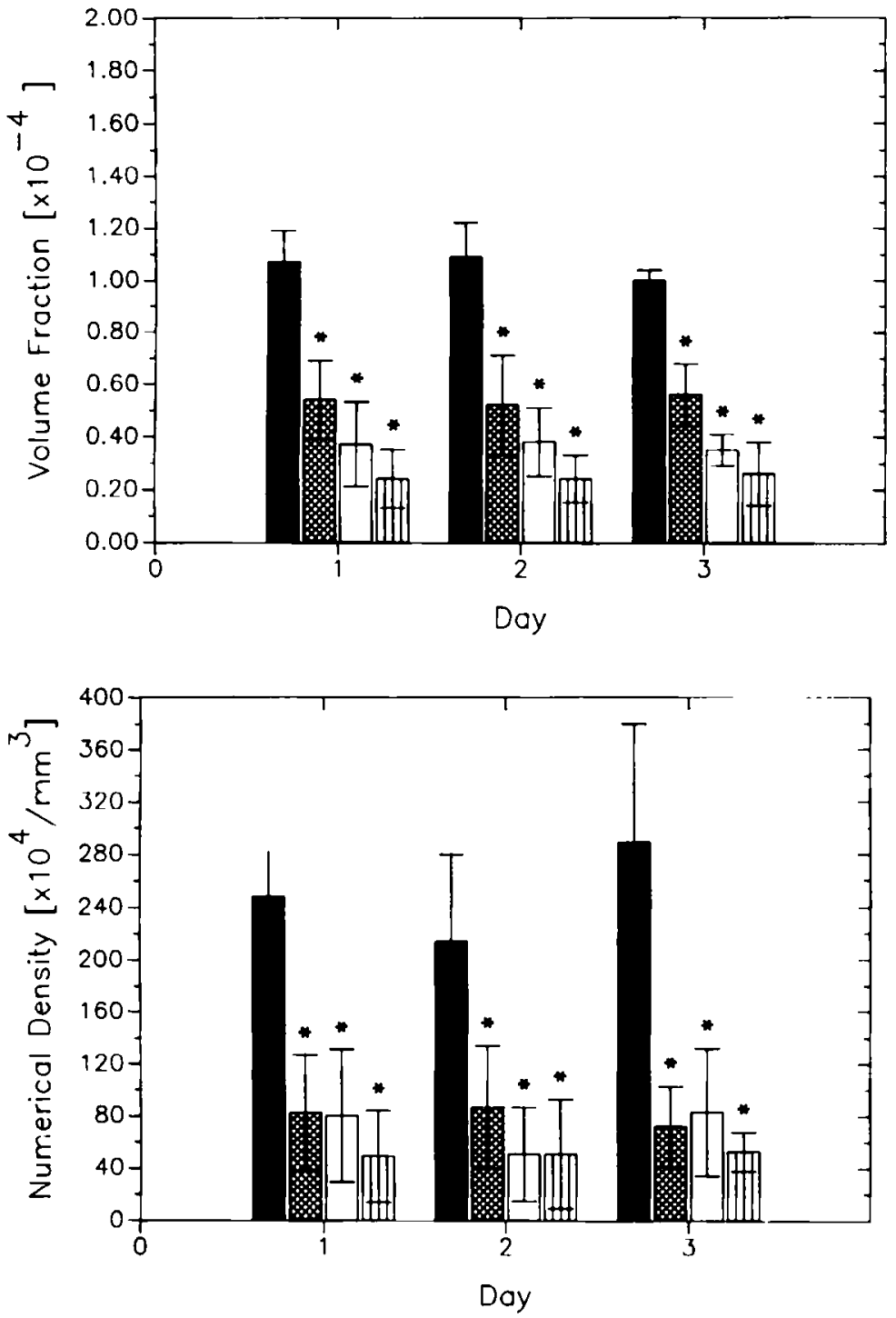

Fig. 4. Volume densitys of total AVs [Vv (AV/ PTC)] in proximal tubular cells. The mean values \pm standard deviation (indicated by the vert $i$ cal bars) of eight animals are shown. Asterisks denote statistically significant differences ( $U$-test). For symbols see legend of Fig. 1
Fig. 5. Numerical densities of total AVs [Nv (AV/ PTC)] in proximal tubular cells. The mean standard deviation (indicated by the vertical bars) of eight animals are shown. Asterisks denote statistically significant differences ( $U$-test). For symbols see legend of Fig. 1

Table 1. AV parameters in PTCs. Mean values and standard deviation of the volume density ( $\mathrm{Vv}$ ), and the numerical density (Nv) of total AVs are listed for controls and experimental groups. Calculation of percentage change: (test group minus controls) $\times 100 /$ controls

\begin{tabular}{|c|c|c|c|c|c|c|c|c|c|}
\hline \multirow[t]{3}{*}{ Parameter } & \multirow[t]{3}{*}{ DAT } & \multicolumn{3}{|l|}{ Group } & & & & & \multirow[t]{3}{*}{ VA } \\
\hline & & $\mathrm{C}$ & $\mathrm{D}$ & & \multirow{2}{*}{$\mathbf{N}$} & & DN & & \\
\hline & & & & $\%-C$ & & $\%-C$ & & $\%-C$ & \\
\hline \multirow{2}{*}{$\begin{array}{l}\mathrm{Vv}(\mathrm{Av} / \mathrm{PTC}) \\
\left(\times 10^{-4}\right)\end{array}$} & 1 & $1.07 \pm 0.12$ & $0.37 \pm 0.16$ & -65 & $0.54 \pm 0.16$ & -50 & $0.24 \pm 0.11$ & -78 & $*$ \\
\hline & $\begin{array}{l}2 \\
3\end{array}$ & $\begin{array}{l}1.09 \pm 0.13 \\
1.00 \pm 0.05\end{array}$ & $\begin{array}{l}0.38 \pm 0.13 \\
0.35 \pm 0.07\end{array}$ & $\begin{array}{l}-65 \\
-65\end{array}$ & $\begin{array}{l}0.52 \pm 0.20 \\
0.56 \pm 0.12\end{array}$ & $\begin{array}{l}-52 \\
-44\end{array}$ & $\begin{array}{l}0.24 \pm 0.09 \\
0.27 \pm 0.13\end{array}$ & $\begin{array}{l}-78 \\
-73\end{array}$ & $*$ \\
\hline \multirow{2}{*}{$\begin{array}{l}\mathrm{Nv}(\mathrm{Av} / \mathrm{PTC}) \\
\left(\times 10^{4} / \mathrm{mm}^{3}\right)\end{array}$} & 1 & $248 \pm 72$ & $80 \pm 51$ & -68 & $83 \pm 45$ & -66 & $50 \pm 35$ & -80 & $*$ \\
\hline & $\begin{array}{l}2 \\
3\end{array}$ & $\begin{array}{l}214 \pm 36 \\
289 \pm 91\end{array}$ & $\begin{array}{l}52 \pm 36 \\
84 \pm 49\end{array}$ & $\begin{array}{l}-76 \\
-71\end{array}$ & $\begin{array}{l}87 \pm 47 \\
72 \pm 31\end{array}$ & $\begin{array}{l}-59 \\
-75\end{array}$ & $\begin{array}{l}51 \pm 42 \\
53 \pm 16\end{array}$ & $\begin{array}{l}-76 \\
-82\end{array}$ & $*$ \\
\hline
\end{tabular}

DAT, Days after treatment; C, controls; D, diabetes; N, nephrectomy; DN, diabetes + nephrectomy; VA, variance analysis; \%-C, percent of change; PTC, proximal tubular cell; ${ }^{*} P<0.0001$

difference was statistically significant only at the third day. In contrast to this observation, the difference in the volume density of AVs between the DN and the $\mathrm{N}$ groups was already statistically significant after the first day. However, no difference could be found between groups $\mathrm{D}$ and $\mathrm{DN}$.

The total AV-compartment in the control group was composed of $56( \pm 2) \%$ ergs, $38( \pm 1) \%$ mitochondria, and 
$6( \pm 2) \%$ peroxisomes. This was in agreement with the data described in detail in rat PTCs in an earlier paper (Pfeifer and Scheller 1975). No substantial differences were noted in the composition of the AV compartment between the control and experimental groups.

As seen in Fig. 5 and Table 1, the numerical, like the volume density of the AVs is significantly reduced in the experimental groups (D, N and DN) compared with controls. There were, however, no major differences between the STZ-diabetic and nephrectomized rats during the 3-day experimental period.

\section{Discussion}

Compared with other organs and tissues, the kidney appears to be exceptional in that it shows marked growth in the early stages of diabetes mellitus, thus contrasting with the general pattern of protein loss which characterizes this metabolic disorder (Pain and Garlick 1974). It can be shown in the experimental model of diabetes mellitus induced by STZ, a beta-cytotoxic product of Streptomyces achromogenes (Brosky and Sogothethopoulos 1971), by insulin treatment (Seyer-Hansen 1976) or renal transplantation (Lee et al. 1984) that this increase in kidney mass is not due to a direct action of the toxin, but is rather the consequence of the functional and metabolic alterations characterizing the diabetic state. Among these functional consequences, the increases in nephron plasma flow (Hostetter et al. 1981) glomerular filtration rate (Hostetter et al. 1981; Finn 1982) $\mathrm{Na}^{+}, \mathrm{K}^{+}$-ATPase activity (Wald and Popovtzer 1984, Ku et al. 1987) and glucose and $\mathrm{Na}^{+}$reabsorption (Harris et al. 1986; Seyer-Hansen 1987), and the induction of osmotic diuresis (Hostetter et al. 1981; Finn 1982) may be of relevance here. As a morphological correlation of these functional alterations, an increase in glomeralar filtration surface area was found by stereologic investigations (Osterby et al. 1978, Krostrup et al. 1977).

Although the causative factors appear to be different, the growth effect in early experimental diabetes is similar to that observed in the classical experimental model of induced kidney growth, i.e. compensatory hypertrophy after unilateral nephrectomy. The present data are in aggreement with those from the literature which show that the growth response is of the same order of magnitude in both diabetic and compensatory hypertrophy (Seyer-Hansen 1978). In contrast to the latter study, a significant additive effect on kidney growth was not be observed in the DN animals in the present study. Such a discrepancy may be explained by the observations of Kunjara et al. (1986) showing that the additional growth response induced in diabetic animals by unilateral nephrectomy is more pronounced during the later stages of experimental diabetes.

The present quantitative ultrastructural data confirm earlier findings which showed that the volume and numerical densities of AVs are significantly decreased in the cortical convoluted tubular cells after unilateral nephrectomy (Jurilj and Pfeifer 1985). The additional finding that these parameters are also decreased in early diabetic kidney growth and the fact that the decrease is of the same order of magnitude as in compensatory growth after unilateral nephrectomy can be taken as further support for the hypothesis that inhibition of cellular autophagy is an important factor in growth in several different parenchymal organs (for review see Pfeifer 1982).

As discussed in detail elsewhere, changes in the AV parameters are interpreted here as reflecting changes in the rate of $\mathrm{AV}$ formation and of the degradation of their contents, because alterations in the lifespan of AVs known to occur under the influence of various inhibitors are unlikely to be features of the present experiments. Furthermore the decrease in AV volume and numerical density cannot be interpreted merely as a "dilution" effect due to the increase in kidney mass, since this increase amounts to less than $10 \%$ at day 1 , whereas the AVs are reduced at this time point by $50 \%$ or more.

Although a decrease in kidney AV volume and numerical density could be expected during renal growth, this finding appears to conflict with the known effects of insulin PTCs in the normal kidney. As reported earlier (Pfeifer and Wahrmuth-Metz 1983), the volume and numerical density decreases within a short time after both the systemic and local application of insulin, which is in line with the general anticatabolic effect of this hormone. Insulin deficiency as in STZ diabetes should, therefore, increase the AV parameters in the kidney. It appears that the still unclarified factors that are responsible for diabetic kidney growth are more relevant to the regulation of cellular autophagy than the isolated action of insulin on these tubular cells.

Among the factors discussed as being decisive in the induction of a growth response in the kidney, the increase in cellular metabolic work should be considered in some detail. The increased load on the nephron in early diabetes and after unilateral nephrectomy has been analyzed particularly with respect to the increase in tubular $\mathrm{Na}^{+}$reabsorption. However, the fact that the growth response, both after unilateral nephrectomy (Katz et al. 1978) and diabetic hypertrophy (Seyer-Hansen 1987) precedes the maximum $\mathrm{Na}^{+}$load appeared to contradict the work load hypothesis. It has also been shown that unilateral ureteroperitoneostomy, which increases the excretory work of the kidneys, does not stimulate growth to a significant extent (Gittes and Gittes 1984). However, since only a small proportion of the total metabolic work of the kidney is required for excretion, i.e. the production of urine, it would require an analysis of the total metabolic work to determine whether this could be a significant factor in the regulation of kidney growth. The fact that metabolic unloading of specialized parts of the nephron can be associated with stimulation of cellular antophagy, such as occurs in the thick ascending limb of Henle's loop under the influence of furosemide (Bahro et al. 1988), would be in line with the general assumption that work load inhibits cellular autophagy and by this means induces adaptative growth.

Acknowledgement. This work was supported by Deutsche Forschungsgemeinschaft (Pf 95/2-1). 


\section{References}

Bahro M, Gertig G, Pfeifer U (1988) Short-term stimulation of cellular autophagy by furosemide in the thick ascending limb of Henle's loop in the rat kidney. Cell Tiss Res 253:625-629

Bank N, Lahorra MAG, Aynedjian HS, Schlondorff D (1988) Vasoregulatory hormones and the hyperfiltration of diabetes. Am J Physiol 254:F202-F209

Brosky G, Sogothethopoulos J (1971) Streptozotocin diabetes in the mouse and guinea pig. Diabetes 18:606-611

Chevalier RL (1982) Functional adaptation to reduced renal mass in early development. Am J Physiol 242: F190-F196

Dämmrich J, Pfeifer U (1983) Cardiac hypertrophy in rats after supravalvular aortic constriction II. Inhibition of cellular autophagy in hypertrophying cardiomyocytes. Virchows Arch [B] 43:287-307

Fine LG (1986) The biology of renal hypertrophy. Kidney Int 29:619-634

Finn WF (1982) Compensatory renal hypertrophy in SpragueDawley rats. Glomerular ultrafiltration dynamics. Renal Physiol [Basel] 5:222-234

Fleck $\mathrm{CH}$, Bräunlich $\mathrm{H}$ (1984) Kidney function after unilateral nephrectomy. Exp Pathol 25:3-18

Flyvbjerg A, Thorlacius-Ussing O, Naeraa R, Ingerslev J, Orskov $H$ (1988) Kidney tissue somatomedin $C$ and initial renal growth in diabetic and uninephrectomised rats. Diabetologia $31: 310$ 314

Furuno K, Ishikawa T, Kato K (1982) Appearence of autolysosomes in rat liver after leupeptin treatment. J Biochem $91: 1485$ 1491

Gittes GK, Gittes RF (1984) The effect of ureteroperitoneostomy on renal mass in fasted rats. J Urol $131: 1206-1207$

Glaumann H, Eriksson JLE, Marzella L (1981) Mechanisms of intralysosomal degradation with special reference to auto- phagocytosis and heterophagocytosis of cell organelles. Int Rev Cytol 73:149-182

Glaumann H, Ahlberg J (1987) Comparison of different autophagic vacuoles with regard to ultrastructure, enzymatic composition and degradation capacity formation of crinosomes. Exp Mol Pathol 47:346-362

Harris RC, Brenner BM, Seifer JL (1986) Sodium-hydrogen exchange and glucose transport in renal microvillus membrane vesicles from rats with diabetes mellitus. J Clin Invest 77:724 733

Hayslett JP (1979) Functional adaptation to reduction in renal mass. Physiol Rev 59:137-164

Henell F, Glaumann H (1984) Effect of leupeptin on the autophagic vacuolar system of rat hepatocytes. Correlation between ultrastructure and degradation of membrane and cytosolic proteins. Lab Invest $51: 46-56$

Henell F, Berkenstam A, Ahlberg J, Glaumann H (1987) Degradation of short- and long-lived proteins in perfused liver and in isolated autophagic vacuoles-lysosomes. Exp Mol Pathol 46:114

Hill JM, Malamud D (1974) Decreased protein catabolism during stimulated growth. FEBS Lett 46:308-311

Hirose K, Tsuchida H, Osterby R, Gundersen HJG (1980) A strong correlation between glomerular filtration rate and filtration surface in diabetic kidney hyperfunction. Lab Invest 43:434-437

Hostetter TH, Olson JL, Reunke HG, Venkatachalam MA, Brenner BM (1981) Hyperfiltration in remmant nephrons: a potentially adverse response to ablation. Am J Physiol 241 : F85-F93

Jensen PK, Christiansen JS, Steven K, Parving HH (1981) Renal function in streptozotocin diabetic rats. Diabetologia 21:409414

Jurilj N, Pfeifer U (1985) Hemmung der cellulären Autophagie im Nierentubulus als frühe Reaktion nach unilateraler Nephrektomie. Verh Dtsch Ges Pathol 69:479

Jurilj N, Pfeifer U (1990) Inhibition of cellular autophagy in kidney tubular cells stimulated to grow by unilateral nephrectomy. Virchows Arch [B] 59:32-37
Katz AL, Toback FG, Lindheimer MD (1978) The role of renal "work" in compensatory kidney growth. Yale J Biol Med $51: 331-337$

Kleinman KS, Fine LG (1988) Prognostic implications of renal hypertrophy in diabetes mellitus. Diabetes [Metab Rev] 4:179189

Krostrup JP, Gundersen HJG, Osterby R (1977) Glomerular size and structure in diabetes mellitus III. Early enlargement of the capillary surface. Diabetologia 13:207-210

Ku DD, Roberts RB, Sellers BM, Meezan E (1987) Regression of renal hypertrophy and elevated renal $\mathrm{Na}^{+}, \mathrm{K}^{+}$-ATPase activity after insulin treatment in streptozotocin-diabetic rats. Endocrinology 120:2166-2173

Kunjara S, Sochor M, Greenbaum AL, McLean P (1986) Concentration of phosphoribosyl pyrophosphate in renal hypertrophy. Contrasting effects of early diabetes and unilateral nephrectomy. Biochem J 239:241-244

Kunjara S, Beardsley SJ, Greenbaum AL (1988) Renal hypertrophy in experimental diabetes. The activity of the "de novo" and salvage pathways of protein synthesis. Biochem J 249:911-914

Lee CS, Maner SM, Brown DM, Sutherland DER, Michel AF, Najarian JS (1984) Renal transplantation in diabetes mellitus in rats. J Exp Med 139:793-800

Luft JH (1961) Improvements in epoxy resin embedding methods. J Biophys Biochem Cytol 9:409-414

Marzella L, Glaumann H (1980) Increased degradation in rat liver induced by vimblastine II. Morphological characterization. Lab Invest $42: 18-27$

Millonig G (1962) Further observations on a phosphate buffer for osmium solutions in fixation. Proc Vth Int. Congress electron microscopy, Philadelphia, vol 2. Academic Press, New York London, $\mathrm{p} 8$

Mogensen CE, Osterby R, Gundersen HJG (1979) Early functional and morphologic vascular renal consequences of the diabetic state. Diabetologia 17:71-76

Mogensen CE, Steffes MW, Deckert T, Christiansen JS (1981) Functional and morphological renal manifestations in diabetes mellitus. Diabetologia $21: 89-93$

Müller J, Pfeifer U, Dämmrich J (1987) Inhibited autophagic degradation uring ACTH-stimulated growth of rat adrenal zona fasciculata. Virchows Arch [B] 52:429-442

Osterby R, Seyer-Hansen K, Gundersen HJG (1978) Rapid increase in filtration surface and basement membrane material in acute diabetes. Diabetologia 15:259

Osterby R (1986) Structural changes in the diabetic kidney. Clin Endocrinol Metab 15:733-751

Pain VM, Garlick PJ (1974) Effect of streptozotocin diabetes and insulin treatment on the rate of protein synthesis in tissues of the rat in vivo. J Biol Chem 249:4510-4514

Pfeifer U (1976) Lysosomen und Autophagie. Verh Dtsch Ges Path, $60: 28-64,1976$

Pfeifer U (1978) Inhibition by insulin of the formation of autophagic vacuoles in rat liver. A morphometric approach to the kinetics of intracellular degradation by autophagy. J Cell Biol 78:152-167

Pfeifer U (1982) Kinetic and subcellular aspects of hypertrophy and atrophy. Int Review Exp Pathol 23:1-45

Pfeifer U, Scheller H (1975) A morphometric study of cellular autophagy including diurnal variations in kidney tubules of normal rats. J Cell Biol 64:608-621

Pfeifer U, Bertling J (1977) A morphometric study of the inhibition of autophagic degradation during restorative growth of liver cells in rats re-fed after starvation. Virchows Arch [B] 24:109120

Pfeifer U, Jurilj N (1979) Hemmung des intrazellulären Organellenabbaues als Prinzip der Wachstumsregulation in Leber und Niere Verh Dtsch Ges Pathol, 63:503

Pfeifer U, Warmuth-Metz M (1983) Inhibition by insulin of cellular autophagy in proximal tubular cells of rat kidney. Am J Physiol 244 [Endocrinol Metab 7]:E109-E114 
Pfeifer U, Föhr J, Wilhem W, Dämmrich J (1987) Short-term inhibition of cardiac cellular autophagy by isoproterenol. $\mathrm{J} \mathrm{Mol}$ Cell Cardiol 19:1179-1184

Rasch R, Rytter-Nörgaard JO (1983) Renal enlargement: comparative autoradiographic studies of $3 \mathrm{H}$-thymidine uptake in diabetic and uninephrectomised rats. Diabetologia 25:280-287

Richardson KC, Jarett L, Finke EH (1960) Embedding in epoxy resins for ultrathin sectioining in electron microscopy. Stain Technol 35:313-323

Ross J, Goldman JK (1971) Effect of streptozotocin-induced diabetes on kidney weight and compensatory hypertrophy in the rat. Endocrinology 88:1079-1082

Seglen PO, Grinde B, Solheim AL (1979) Inhibition of the lysosomal pathway of protein degradation in isolated rat hepatocytes by hepatocytes by ammonia, methylamine, chloroquine and leupeptin. Eur J Biochem 95:215-225

Seyer-Hansen K (1976) Renal hypertrophy in streptozotocin-diabetic rats. Clin Sci Mol Med 51:551-555
Seyer-Hansen K (1978) Renal hypertrophy in experimental diabetes: a comparation to compensatory hypertrophy. Diabetologia $14: 325-328$

Seyer-Hansen K (1983) Renal hypertrophy in experimental diabetes mellitus. Kidney Int 23:643-646

Seyer-Hansen K (1987) Renal hypertrophy in experimental diabetes: some functional aspects. J Diabetic Complic 1:7-10

Viberti GC, Wiseman MJ (1986) The kidney in diabetes: significance of the early abnormalities. Clin Endocrinol Metab 15:753-782

Wald H, Popovtzer MM (1984) The effect of streptozotocin induced diabetes mellitus on urinary excretion of sodium and renal $\mathrm{Na}^{+}, \mathrm{K}^{+}$-ATPase activity. Pfluegers Arch 401:97-100

Weibel ER (1969) Stereological principles for morphometry in electron microscopic cytology. Int Rev Cytol 26:235-302 